\title{
Bonegilla Heritage Park: Contesting and Coordinating a Public History Site
}

\author{
ALEXANDRA DELLIOS
}

$\mathrm{F}$ or nearly twenty years, the site of the former Bonegilla Migrant Reception and Training Centre was publically neglected. It was a derelict site pulsing with personal memories, some fond, others melancholy. These memories form the fragments of many migrant journeys. Publically, and in relation to the wider national narrative of the successful post-war migration scheme, Bonegilla had little collective significance. It was only in the years leading up to the bicentenary of 1988 that memories surrounding the former migrant camp began to emerge and converge around new narratives, ones that marked the site as place of national significance, progress and success. These narratives have been developing ever since, evolving and responding to changes in our wider attitudes to 'multicultural nationhood', heritage preservation and structural changes to Bonegilla's administration and marketing. ${ }^{1}$ The relaunch of Bonegilla's Migrant Experience Heritage Park in September 2010 is but one step in the evolution of Bonegilla's public history, one we 
might typify as part of the move from sporadic ex-resident-led anniversaries to a more concerted heritage and state-led endeavour. This process can also be explained in reference to Ashton and Hamilton's theory of 'retrospective commemoration': the effort of state authorities at all levels to 'express a more inclusive narrative of the nation as result of, among other things, multicultural policies by retrospectively commemorating a wider number of communities and people who have contributed to Australia's "national development".'2

Once an integral part of the government's post-war immigration scheme, Bonegilla was a temporary home for some 320000 European displaced persons and assisted migrants, making it the largest of Australia's post-war migrant camps. The original site of unlined weatherboard huts was quickly converted from an Army Training Camp into a Migrant Reception and Training Centre in 1947. This was a modest and makeshift arrangement, much needed in a post-war Australia with a severe housing shortage. Bonegilla was part of a larger system of migrant reception centres. They were organising points from which to assign employment to displaced persons and assisted migrants who had exchanged two years of their labour for assisted or free passage.

Bonegilla was located in a remote part of northern Victoria, between the border towns of Albury and Wodonga. This remote location suited the government, which anxiously anticipated an adverse response from 'Old Australians' to the new migrant presence. ${ }^{3}$ From the organising point of Bonegilla, migrants were to be 'dispersed' amongst the Australian population. ${ }^{4}$ An assimilationist rationale and post-war demands in the economy directed their movements.

After its closure in 1971, Bonegilla was handed back to the army. Part of the former site became Latchford Barracks. For the next twenty years most of Bonegilla's remaining original infrastructure was demolished or fell into disrepair. The camp was seen as a slightly shameful footnote to Australia's immigration history. For many, it was a tragic and isolating place and a reminder of Australia's discarded migration policies - of ethnic discrimination, containment, control and assimilation. ${ }^{5}$ So, by the 1970s, Bonegilla had disappeared from the public consciousness, along with the last vestiges of official assimilation.

The site remained invisible until the mid1980s when the army made known its plans to sell off, or else demolish, the remaining huts of Block $19 .{ }^{6}$ Since this time, efforts to publically commemorate Bonegilla, while intermittent, have increased. This has included reunions and anniversaries, state and national heritage listings, the erection of permanent museum displays, temporary and touring exhibitions, the onsite Heritage Park and popular culture in the form of television and 
news-reporting. For the national audience, as well as several ethnic communities, Bonegilla now plays a role in the collective imagination of the post-war period and the migrant journey. As Sara Wills notes, Bonegilla is the most publicly 'remembered' - for better or worse - of all Australia's post-war migrant camps. ${ }^{7}$ Most importantly, the nature of its public representation has evolved since the late 1980s. Bonegilla is much more than a place of personal migrant memory, and its previous negative connotations in the public arena have all but been erased.

How do we explain this public transformation? Certain actors and processes are easy enough to identify in regards to the construction and evolution of the Heritage Park. We can point to the role of ethnic communities' councils, Albury and Wodonga city councils, state heritage bodies, the Victorian Multicultural Commission, the Greek-led exresidents association and the Bonegilla Migrant Experience Advisory Committee, most of which represent various State interests. But a deeper understanding of the evolution of Bonegilla's public history involves understanding the contestation and co-ordination of collective memories: that is, multiple narratives of Bonegilla's past, which, while in constant dialogue with each other, are framed and sanctioned by the limits of Australian multiculturalism and heritage discourses, narratives sanctioned by 'retrospective commemoration' ${ }^{8}$ Indeed, as Ashton and Hamilton highlight, within these narratives 'communities and organisations need to operate if they are to be officially part of the national story and its regional and local variants'. ${ }^{9}$ This article progresses from this premise, and takes the evolution of the on-site Heritage Park as a specific example of the changes to Bonegilla's public history. The Heritage Park - one expression among many in Bonegilla's chequered public history - is encompassed by wider discursive, spatial and visual elements that shape collective remembrance including national heritage, multiculturalism and the homogenous 'migrant experience'. ${ }^{10}$

Since Glenda Sluga's attempts to trace the 'Bonegilla myth-making' emerging in the late 1980s, a few concerted attempts have been made to interrogate the nature and function of collective and public memories of Bonegilla and other post-war migrant camps. ${ }^{11}$ These are significant sites in the history of Australia's post-war migration scheme. As historic sites they illuminate and represent the strategic and political motivations behind that remarkable period in Australia's immigration history, as well as the plight of hundreds of thousands of displaced persons and, later, assisted migrants.

What Sluga sees as separate and oppositional discourses - the official and vernacular Bonegilla - have continued to converge and co- 
ordinate in official public history sites. Bruce Pennay - public historian, heritage consultant, and key member of the Bonegilla Heritage Park Advisory Committee - has previously explored the construction of Block 19 as a public memory place, a process in which he was involved. ${ }^{12}$ Pennay traces the collective significance of Bonegilla's official heritage listings, which not only contributed to the increasing 'memory bank' surrounding the site, but also gave the Bonegilla narrative official sanction. He stops short of extrapolating from these analyses of the heritage listing of Bonegilla, neglecting to comment on their implications for the collective reception and construction of Bonegilla memories. He observed: 'That kind of analysis awaits someone more confident than I am of detecting fine trends in narratives of the nation over the brief twenty year time span of these heritage listings' ${ }^{13}$ This statement rightly presumes that narratives of the nation have been central to public histories of Bonegilla, and, more importantly, that these narratives have evolved since 1988, especially in regards to the public reception of the contentious policy and ideology of multiculturalism. He states that the National Heritage Listing of Bonegilla in 2007 was proof that Bonegilla had become part of other 'government approved stories of the making of the nation. ${ }^{14} \mathrm{~A}$ more concerted analysis of these narratives requires an understanding of the processes and actors involved in this 'making'.

Jayne Persian has argued, in opposition to Pennay, that Bonegilla's success as a place of national commemoration in particular is debateable. Persian is primarily concerned with the involvement of displaced persons in these heritage process. She interprets their lack of active involvement in these official processes as apathy towards Bonegilla as a memory site and therefore a rejection of the multicultural narrative. Consequently, she argues that the site has been 'appropriated' by the nation in the service of multiculturalism - an attempt to 'infuse Australia's national story with migration as a trope of nationalism'. ${ }^{15}$ Persian has some grounds on which to base her case, having interviewed a handful of former displaced persons, whom she insisted had little interest in the site beyond family memories. But her summarily applied assumptions also undermine those ex-resident groups and individuals implicated in the site's commemoration. This includes those actively involved in former resident groups and local councils as well as those who attend the anniversaries, donate material or view the Bonegilla Collection and exhibition at the Albury Library-Museum, travel to the former site with family and friends or those who seek out any mention of the camp at more accessible places like Melbourne's Immigration Museum. ${ }^{16}$ Some, as Ashton also highlights, adhere to a multicultural narrative or migrant success story as a means to feel included in the 
national narrative, however limited it may be. The testimonies and writings contained in the Bonegilla Collection indicate that they feel Bonegilla's public recognition imbues their personal pasts with significance so that their family histories become History with a capital H. ${ }^{17}$ Of course, responses to public history are multiple. Encapsulating or typifying the 'collective' response to Bonegilla's public history is not only impossible but methodologically insidious. A study that moves beyond representational analysis would consider the processes and peoples that surround public history efforts, how groups and individuals get invested in the site and what responses and uses (however multiple) they make of it. Developing schemas for different types of memory studies aim to understand the function and circulation of public histories and their relation to collective and individual memories. With this in mind, I hope not to fall pray to the desire to announce another Authoritative Account of what Bonegilla should mean to us as a migrant nation.

In our exchanges, Pennay was wary of my using the term 'collective memory' ${ }^{18}$ Naturally, he was curious to know whether it was a Greek Bonegilla, a Dutch Bonegilla or Albury-Wodonga's Bonegilla. Since 1987, it has become all three, and more, as these actors have involved themselves in the commemoration of the site and sometimes adhered to dominant narratives. Overwhelmingly, since the late 1980s, Bonegilla has become more than just a place of migrant memory. Ownership has been consciously extended through a long and interactive process of contestation and co-ordination, to incorporate local (Albury-Wodonga) and national communities (heritage). In the process, Bonegilla's public meaning has been simplified on some levels, but also taken beyond its previous narrative as a 'place of no hope'. Bonegilla is 'received' by a wider audience/s outside the individual, familial and ethnic memory networks that have previously typified what Sluga calls 'vernacular' forms. ${ }^{19}$

Sluga remains apprehensive of commemorating Bonegilla, believing the official voice is trampling the migrant or vernacular voice in most forms of public history. ${ }^{20}$ There is a sense that official frameworks, which trumpet the progressive timeline of Australian history and Bonegilla's role in the formation of a multicultural present, have the potential to 'colonise' or even silence personal or migrant memory with stock narratives about the state and nation. ${ }^{21}$ But I retreat from this line of inquiry and from the clear separation of official and vernacular memories. On one level, the personal is always somehow framed by a wider collective conception of the self, whether ethnic, familial, national 
or local. This approach rest at the centre of most work on collective memory, especially work that places itself at the interdisciplinary nexus of sociology and history, which stems from the earliest theorising done by Maruice Halbwachs. ${ }^{22}$ Similarly, oral historians have also recognised that we all seek to link our histories to larger historical processes. These narratives allow us to anchor ourselves in time and space. I am not arguing that one version of Bonegilla's collective memory is propagated by, and received at, all public history sites and acts. However, the State narrative's 'revisionist conservative' version of multiculturalism - as the inevitable and harmonious outcome of Australia's post-war immigration scheme - has had an undeniably pervasive effect on how Bonegilla is expressed and received by all levels of memory - ethnic, familial, national, local. ${ }^{23}$ Irwin-Zarecka prefers to think of this process as 'framing' rather than 'dominating' the memories of others. ${ }^{24}$ Certainly, the memories of some groups often speak louder than others. But tracing these processes involves understanding their articulation in a given framework.

Before progressing, it is necessary to place Bonegilla's commemoration in a wider context of public remembering in Australia. We have witnessed a boom in heritage advocacy and conservation in the last thirty years, particularly since the 1988 Bicentenary. The idea of a 'multicultural past' or a 'multicultural heritage' is a relatively novel introduction to Australian public discourse. Since the 1980s, and with bipartisan support for the government-sanctioned policy of multiculturalism, ethnic organisations have become more prominent and vocal, albeit in a framework dictated by the official definition of multicultural nationhood, ambiguously defined as 'unity in diversity'. Nonetheless, ethnic organisations have played their part in celebrating and commemorating their pasts in Australia, some more successfully than others. The Victorian Multicultural Commission, the Multicultural Heritage body under the NSW Heritage Branch and The NSW Migration Heritage Centre at the Powerhouse Museum (a separate initiative) have also been active in funding oral history projects and exhibitions on the history of separate ethnic groups. The latter group, as well as staff at History SA are working to create online indexes and information on all former migrant hostels in their respective states. There have been reunions at Bonegilla, Bathurst, Greta and West Sale migrant camps (some of them in association with National Heritage Week). ${ }^{25}$ The Australian National Maritime Museum, Melbourne's Immigration Museum, Adelaide's Migration and Settlement Museum and Bonegilla itself have erected 'welcome' or 'tribute' walls or gardens which give migrants the opportunity to pay for a plaque, tile or brick with their 
name engraved, commemorating their own journeys and settlement. 'Multicultural' festivals, celebrating the material contributions of respective ethnic groups - more often, long-settled, European post-war migrants which claim to celebrate our 'multicultural heritage' - have also become an annual feature of public life, especially in the self-proclaimed 'cosmopolitan' city of Melbourne.

Despite rising opposition to Asian immigration, the 1980s can be seen as the peak of celebratory multiculturalism in Australia. ${ }^{26}$ Multiculturalism was a political policy and ideology created in the mid1970s. It was explicitly launched by the Whitlam government as an alternative to the policy of integration, the weaker heir to assimilation. Since then, multiculturalism has received bipartisan support as an ideology and policy that addresses and contains our inevitable cultural plurality. Arguably, the 1980s was also a period that trivialised 'ethnic culture'. An outwardly superficial multiculturalism gained sanction in the popular press. The material contributions of respective ethnic groups were applauded. Their distinctive and static 'ethnic' cultures, which often translated to an unchanging 'food and folklore', were celebrated as something to be guarded and maintained. ${ }^{27}$

It was in this context that Bonegilla re-emerged. It was maintained by the army from 1971 to the late 1980s. The intention was to use only a quarter of the site, allow the remaining huts to fall beyond repair and eventually demolish them and sell the land. ${ }^{28}$ As the Bicentenary approached, and as discussions of national identity and multiculturalism dominated the public sphere, some ex-residents of Bonegilla began to express interest in preserving the site for 'posterity'. ${ }^{29}$ The Bonegilla Immigration Museum Committee, made up of mainly former residents, was established in 1984 in response to the army's threats of demolition. The committee aimed to garner support for the establishment of an onsite immigration museum commemorating the former migrant camp. ${ }^{30}$ This idea was supported by the local paper, the Border Morning Mail and Melbourne's Sun Herald and nominally by the Minister for Immigration, Chris Hurford - without the official backing of his government. ${ }^{31}$ Like the oral historians and part-time exhibition curators of the time, some sections of the press began to tell the stories of individual migrants. ${ }^{32}$ Not surprisingly, Bonegilla appeared in many of their stories. It became popular to report that over 320000 Australians had passed through the reception and training centre over its twenty-four year history. ${ }^{33}$ Some of those behind the Bonegilla Museum Committee proposed that Bonegilla was the beginnings of Australia's multicultural present, a popular trope that recurs to this day. ${ }^{34}$ However, in the 1980s this particular contention 
had to work against the idea, unchallenged since Bonegilla's closure in 1971, that the migrant camp was an embarrassing and tragic reminder of Australia's discarded migration policies which involved ethnic discrimination, containment, control and assimilation. ${ }^{35}$

In 1986, the Bonegilla Museum Committee was denied permission to include a Bonegilla event on the Bicentennial program and the Australian Bicentennial Authority (ABA) declined to offer financial support to the Committee and its plans for a national immigration museum. ${ }^{36}$ Despite tensions surrounding it, multiculturalism and its superficial projections of ethnic food and folklore were key themes in the 1988 Bicentennial celebrations. Multiculturalism remained, as Stephen Castles highlights, at 'the level of trivial pursuit' ${ }^{37}$ Clearly, Bonegilla evoked more than food and folklore. The ABA favoured a more accessible and less contentious space in one of the major urban centres to tell the history of immigration. ${ }^{38}$ This idea which was acceptable to the army, which still owned the Bonegilla site and made its own claims over its history as an army camp. In the late 1980s, it was not yet clear which aspects of the Bonegilla narrative would dominate its public representation nor how it would come to publically symbolise a collective and homogenous migrant journey, one that could be included in a national narrative. For the wider public, Bonegilla still held negative connotations. While many of the more insidious elements of Bonegilla's history remain hidden - child malnutrition in 1949, suicides and enforced family separation - its re-emergence in public history was not in line with the celebratory tone of the Bicentenary or the superficial public persona of multiculturalism itself. ${ }^{39}$ It was neither officially nor popularly integrated into a collective memory of the 'migrant experience' as it exists today.

Although ex-residents failed to garner enough support for a national immigration museum, a massive reunion and festival was held in 1987. More than 2000 'ex-Bonegillians' and their families from all over the nation attended this fortieth anniversary and Back to Bonegilla festival in December $1987 .{ }^{40}$ They looked on the event as a personal opportunity to reunite and reminisce with old friends. ${ }^{41}$ This, at least, is what the mainstream press said of the event. ${ }^{42}$ As Sluga suggest in her 1988 monograph, despite the official 'constraints of the program' - the presence of Mick Young, Minister for Immigration, and his speeches linking Bonegilla to the successful realisation of multiculturalism - the 'vernacular' interests of ex-residents 'took over the day and the site for themselves' ${ }^{43}$ While the nation did not fully embrace the Bonegilla narrative, some 2000 individuals embraced the opportunity to remember their individual Bonegilla experiences, whether tragic or joyous. This is 
not to suggest that the articulation of their memories were not in some way/s framed by the narrative of the migrant success story-and other discursive frameworks of social identity - and the tempting progress and collective meaning attributed to their lives by a retrospective narrative of multicultural nationhood.

Despite this burst of attention in the late 1980s, Bonegilla remained a small collection of unused and slowly dilapidating huts with no conservation plan pending. In order to be preserved, as per the wishes of the Museum Committee, the site needed official - that is, the state backing and funds. This required significant public emotional investment-something Bonegilla had not yet garnered. While the army abandoned its plans to demolish the remaining twenty-eight huts after the site was placed on the Register of the National Estate in 1990, the Bonegilla Museum Committee disbanded in 1991. The Committee blamed this on the lack of 'non-migrant' interest and support. ${ }^{44}$ All the materials they had collected as part of the 1987 festival were moved to Adelaide's new Migration and Settlement Museum. ${ }^{45}$ Lack of continuous public and national investment - which necessarily relies on a coherent and appealing narrative - prevented the site's infrastructure from developing and progressing as an official 'memory place'.

Nonetheless, the site continued to hold some significance for individual migrant groups and families. Bonegilla's continued public remembrance depended on these 'participatory' and performative forms of commemoration. From 1991, a segment of Melbourne's Greek community organised annual 'sentimental visits' to Bonegilla as part of the Greek Antipodes Festival. ${ }^{46}$ Calls to establish a permanent monument of some sort at Bonegilla were intermittent. Eventually, Albury Regional Museum acquired the Bonegilla Collection from Adelaide and in 1996 an extensive conservation management plan commissioned by the Department of Defense was prepared by Freeman Leeson Architects and Ruth Daniel. ${ }^{47}$ As a result of this plan, the army relinquished its hold over the site and agreed to transfer Block 19 to the Victorian Government. They in turn transferred responsibility to Albury Wodonga Parklands.

The mid to late 1990s was a contentious time in Australian public and political life. The rise of new conservatism translated to more concerted attacks on the structural outcomes of multiculturalism and its implications for an Australian national identity. A renewed dialogue of 'citizenship' entered the discussion about multiculturalism and the term 'integration' re-appeared. Multiculturalism was often qualified by an end goal of integration-as it still is. The voices of a few notable 
conservative academics and politicians dominated the nation's mainstream media. At times, it seemed that the 'problem' of allocating separate resources to ethnic organisations turned multiculturalism into a dirty word for the downtrodden 'mainstream' ${ }^{48}$ This was the context in which Pauline Hanson garnered support. Not long after Hanson's maiden speech to Parliament, the Friends of Bonegilla Lobby was formed with the support of the inner-Melbourne municipality of Moreland. ${ }^{49}$ It was involved in the successful 1997 fiftieth anniversary celebrations at Bonegilla. ${ }^{50}$

Despite the contentious political landscape, the ten-day anniversary was a resounding success, with up to 30000 pilgrims in attendance. The 1997 anniversary prompted a discussion in the national media of the 'successes' of multiculturalism. In the face of attacks on multiculturalism and immigration, Bonegilla signposted a harmonious present and maintained the myth of migrant social mobility. Ex-residents and their children featured homogenously as successful and integrated Australian citizens. For many ex-residents themselves, the anniversary was a means to rally against Hansonite racism. ${ }^{51}$ Overall, a less trivial and static idea of 'ethnic culture' was paraded, one which showcased the growth and dynamism of individual ethnic communities. For their part, the official organisers - Albury and Wodonga Councils and the Albury Regional Museum - had made explicit their aims for the festival: to use Bonegilla to celebrate the idealisation of a multicultural present.

The anniversary was thus a congratulatory event for both exresidents and a newly constituted national audience. In many ways, the 1997 event was a less personal and more sombre reunion of old friends than the first anniversary. In the print media of the 1990s, Bonegilla had evolved to take on a more concentrated image as a site of national historical significance. It came to adhere to the popular trope of the 'migrant success story'. Social mobility in certain sections of the migrant population did become more evident in the 1990s. In this context, Bonegilla was on its way to being accepted as a site worth preserving for national posterity - an apparently representative example of the postwar migration experience and a marker for our present demographic reality; the 'beginnings of multiculturalism'.$^{52}$ While such a narrative was also promoted by the Bonegilla Museum Committee in the 1980s, it only became affective in the new context of the 1990s in which multiculturalism was struggling to move away from the 'level of trivial pursuit' into a more complex and contentious discussion with national identity and the imagined mainstream.

In the 1990s, certain migrant groups continued to dominate the memory place on site at Block 19. The Dutch established their own 
exhibition in one of the huts. A group of Dutch ex-residents also published a commemorative book on the Dutch experience to coincide with the 1997 anniversary. ${ }^{53}$ The Greeks also continued to hold their separate commemorative events. Italians from the Moreland City Council voiced their personal memories, both fond and melancholy, of Bonegilla. The army was sidelined in Bonegilla's commemoration and heritage assessments. It occasionally made public claims to its importance in Bonegilla's history. Originally, they 'baulked' at the prospect of Bonegilla being declared a heritage site. ${ }^{54}$ The fiercest competition over the projection of Bonegilla's public meaning took place in this earliest period. The army only 'appeared to change its mind' after the site was placed on the Register of the National Estate in 1990, with the heritage assessment containing obligatory reference to Bonegilla's role as an army camp as well as a migrant centre. ${ }^{55}$ However, this narrative remains nominal in Bonegilla's public history. To the nation, it is first and foremost a migrant camp. ${ }^{56}$

In light of these minor successes in Bonegilla's commemoration, a new festival was planned for 1999. The 1999 festival attempted to capitalise on the former festival's success. While the 1997 festival had won the City of Wodonga's Australia Day Award for Most Outstanding Community Event, the 1999 festival fell short of its aspirations. Fewer visitors, including ethnic and ex-resident community groups, and less publicity made for a much smaller event. It was marketed as a local one for Albury and Wodonga. It was a celebration of the region's cultural diversity, a narrative which Pennay is still at pains to promote, but which was clearly pre-emptive in $1999 .{ }^{57}$ The festival did not draw adequately on the support of respective ethnic groups previously involved in Bonegilla's commemoration, especially the Greeks, the Dutch and the Friends of Bonegilla Lobby. The 1999 event was supported by the City of Wodonga and the City of Albury, managed by Investment Albury Wodonga and held in association with annual Albury Wodonga Wine and Food Festival. While a disappointment, this 1999 festival was an indication of the administrative direction the site was to take in the years to come, relying on the interpretive and financial support of Albury and Wodonga.

Throughout this time, ex-resident volunteers, under Parklands Albury-Wodonga, ran the site. This included the Beginning Place, a small open-air monument to Bonegilla migrants built on-site in 2005. The site received grants from the Victorian Multicultural Commission and, after Bonegilla's state heritage listing in 2002, from the Victorian Heritage Council. There was occasional interest shown by councils and 
state bodies. But the day-to-day running of the site relied on enthusiastic volunteers. The remaining huts continued to fall into disrepair. Excepting the successful anniversary events, the site only received occasional visits from ex-residents. There was virtually nothing onsite except the Beginning Place. Researcher Jayne Persian captures the visitor's experience before the September relaunch:

When I visited the site in July 2006, there were few signs and the landscape was one of isolation and emptiness - no staff, a huge unopened café (and hence no public toilets), a small outdoor commemorative platform incorporating little explanation, particularly of the unintelligible soundscape wall, small and rusty silhouettes, locked and graffitied buildings, and holiday cabins for Army personnel. ${ }^{58}$

In 2007, after a successful campaign by Bruce Pennay, Bonegilla was placed on the National Heritage List. According to the plaque erected outside the main entrance to commemorate its national heritage listing, Bonegilla had become, in the span of nineteen years, a 'symbol of postwar migration which transformed Australia's economy, society and culture'. This is a far cry from its previous status as a discarded and shameful place representing out-dated immigration policies. Pennay, referring to the heritage listing, has argued that the local communities of Albury and Wodonga did not 'own Bonegilla, until the nation owned it'. Albury and Wodonga became interested in the site as national heritage, as a place of significance capable of capturing the nation's imagination like Eureka or Glenrowan, one which they could now claim. With local council and community support, the site was able to be propped up as a viable and ongoing tourist attraction.

It is telling, therefore, that despite its heritage listing, the Bonegilla Migrant Experience Advisory Committee was forced to cancel the 2007 anniversary festival due to lack of funding and resources. It had been scheduled for the weekend after the site was placed on the National Heritage List. As Pennay has noted, by the 2000s Bonegilla's commemoration had moved away from collective anniversaries, those previously supported by enthusiastic former residents, migrant groups and the Ethnic Communities Council. Bonegilla's commemoration was now typified by the provision of new exhibitions and heritage assessments under the control and administration of the city Councils, Albury-Wodonga Parklands and state and national heritage bodies. This was at best an uneasy partnership. ${ }^{59}$ 
In place of the cancelled collective anniversary, the Dutch and Greek communities organised their own colourful events. These ethnic-led occasions are more than simply a form of 'vernacular' as opposed to 'official' commemoration. Nor do they trump the argument that Bonegilla is now encased by processes of retrospective commemoration. Officially, these 'participatory' events rely on the framework provided by heritage and multicultural discourses to articulate and frame their memories. They celebrate a progression, the migrant success story, and point to the role of respective (often contained and static) ethnic groups in forming the multicultural nation. This may be therapeutic and perhaps constructive for many individuals who identify themselves as members of respective ethnic groups. We cannot deny the collusion and co-ordination of memories that is involved in this process of publically remembering Bonegilla. There is a constant dialogue between personal and collective memories which reflect the discursive constitution of all memory practices. Public history can involve the coordination, rather than just a contestation, of collective memories. ${ }^{60}$

Journalist Lee Mylne's promotional piece on the Heritage Park, published months before the anniversary's cancellation, provides a glimpse of an image much akin to Persian's. ${ }^{61}$ After Mylne's homogeneous classification of the 'migrant experience' - a popular trope in Australian journalism - she makes mention of Bonegilla's 'cafe built as part of the \$2 million development [which] sits forlorn, the lack of regular visitors making it unviable for now. They trickle in, with the odd organised tour bringing larger numbers' ${ }^{62}$ This 'forlorn' image is not allowed to undermine her role as promoter and guest of Tourism NSW. Indeed, the state heritage involvement in Bonegilla's commemoration is evident. There are token references to funding from Victorian Government and Heritage Victoria. The ongoing heritage site, rather than the occasional anniversary, is the focus of a tourism push. Bonegilla is even compared to America's tourist site and monument to immigration, Ellis Island, a wishful comparison that Pennay has also made. While the current site sits forlorn, the promoters hold high aspirations for its heritage and tourism value, for Bonegilla holds wider national significance. It is a site for a wider tourist market rather than the migrant pilgrim.

Administratively, the site of Bonegilla has undergone many changes since the failed 2007 anniversary. In 2009, the Albury and Wodonga Councils, Parklands Albury-Wodonga and the Bonegilla Migrant Experience Advisory Committee (itself consisting of council members and a few local ex-residents) signed a memorandum under the 
Department of Environment, Water, Heritage and the Arts. They agreed to share the maintenance and running of the Bonegilla Heritage Park. Parklands remains in control of the site's physical maintenance and the councils, along with the Advisory Committee, have taken over the 'interpretative role'. They have attempted to provide a more concerted and refined narrative, building and including themselves into the epic memory of post-war migration. Whilst maintaining the focus on the (homogenous) migrant experience, they have also, in response to Pennay's suggestions, appealed to the local community to build 'local ownership' of the site. ${ }^{63}$

The site was relaunched in September last year. The huts have been repainted and the wooden floors repaired, new exhibitions set up, the Dutch exhibition transposed and the visitor centre restocked with new merchandise including $t$-shirts, mugs, and postcards and a new audio tour. Bonegilla Heritage Park has subsequently attracted a wider range of visitors and garnered more publicity from inside and outside AlburyWodonga. ${ }^{64}$ Visitors before 2010 were mainly ex-resident pilgrims. But the current site co-ordinator, Bernadette Zanet, has announced an increase in tourists, particularly the 'heritage goers' and the older 'grey nomads ${ }^{\prime}{ }^{65}$ In April-May 2011, the site attracted approximately 950 visitors. In previous years, it would have expected only thirty per month. While Bonegilla could always expect to receive annual busloads of Greek ex-residents from Melbourne, it now receives regular bus loads of tourist, local community groups and Victorian school children. ${ }^{66}$ Individuals come in search of the most obscure connection to Bonegilla. When I visited the site in May 2011, I listened to fellow visitors who recalled camping near the site when it was in operation as a migrant camp. This enabled them to include themselves in what is now a larger historical narrative of national importance, a legitimacy Bonegilla has gained via its heritage listing and the official discourses that surround this.

These processes have implications for the meaning and significance of Bonegilla's collective memory. Can it still be called a memory place for migrants? Certainly, the current management admit that city councils and the Advisory Committee now have to seek and prompt migrant community involvement. This is a significant development in Bonegilla's commemoration, one that runs counter to the history of Bonegilla's conservation in the late 1980s its earlier 'participatory memorialisation'.

Sara Wills suggests that Bonegilla might offer a constructive history, a 'productive sadness' that reminds us of the values of providing more extensive settlement services for new settlers. ${ }^{67}$ In the last decade, and especially since September 11, debates over Australian immigration have 
been usurped by a concern, and near hysteria, over so-called illegal immigration and the policy of mandatory detention and offshore processing for asylum seekers. Wills suggests that while Bonegilla may provide a positive model for a new 'ethics of care' for refugees, we should avoid 'pride in the nation's past' and thus a recovery from our present shame ${ }^{68}$ Increasingly, Bonegilla is used as an example of the 'national cuddle'. ${ }^{69}$ And even as volunteer workers at the Heritage Park refer to the 'Spartan conditions' and deep-pit latrines of a past Bonegilla, the real drama resides in the epic success story - the social advancement of Australia's diverse ethnic groups who passed through the camp. Ironically, in the period immediately after its closure in 1971, the shame that partly explains Bonegilla's silencing was most probably a result of the more extensive and comfortable housing on offer to newly arrived Southeast Asian refugees, in the form of specially-built flats and community housing. Thus a system replaced the obsolete and shoddy use of remote migrant camps such as Bonegilla. Furthermore, the 'ethics of care' provided to newly arrived British assisted migrants in inner-city hostels surpassed that on offer in remote migrant camps like Bonegilla.

Bonegilla is now marketed on the back of its National Heritage Listing. Zanet recounts the difficulties of marketing heritage as 'not just old buildings, but culture' ${ }^{70}$ In effect, by arguing that culture can be marketed as heritage - in the same way that heritage discourses have for some time now - the Bonegilla heritage park offers distinct cultures as archaic and preserved in time and space, preserved behind glass cabinets and display panels, and, most importantly, as something now owned by the national narrative. This representation of multiculturalism as static and contained is a familiar feature of migration museums and exhibitions of migration or 'diversity'.$^{71}$ A homogenous post-war migrant 'culture', is presented as unaffected by the layers of time - much like the site of Bonegilla itself - as unaffected by the layers of reinterpretation, reconstruction and adjustment that are inherent in any public history site.

The new exhibitions themselves, those installed in September, are inevitably inconsistent. To capture the migrant experience of some 320 000 displaced persons and assisted migrants over a twenty-four year history is a neigh impossible task. Not all voices will be aired. As such, the exhibitions aim to re-enact and evoke select aspects this migrant experience. Most huts contain information panels, organised at first under chronological and then thematic headings: arriving, employment, accommodation, a new land and catering. Not all of the panels correspond with the material contents of the exhibitions within 
respective huts. The exhibitions themselves rely on the authority of physical objects to retell isolated stories. While the objects are antiquarian, underlining the distance between past and present, there is no historical context in which to place and understand the object. They are a receptacle for a fragmentary memory of the migrant journey. Donated or discarded everyday objects - worn shoes, an old basket-ball, national costumes, an old iron - rest behind glass cabinets.

Examples abound of how the lack of historical context - and an absence of explanation of the processes and outcomes of the migration scheme - renders the Heritage Park's attempts at a homogenous narrative of the 'migrant experience' fragmentary. Some exhibitions reproduce the sights and sounds of Bonegilla. In the mess hall, tourists can hear the sounds of communal dining. Further on in this display is an elaborate reproduction of a family table setting from the 1950s. Such a set-up, with the exception of the staff huts and long-term residents, was not common within the communal dining halls in which most new arrivals ate their breakfast, lunch and dinner. It becomes difficult for the interested tourist to make sense of the huts' contents. At moments, the site is austere and antiquarian, in others interactive yet trivial. Perhaps most importantly, the history of the government's sometimes neglectful, occasionally heavy-handed, but overall extensive post-war immigration scheme is lacking. Perhaps these fragmentary outcomes are inevitable in an exhibition that attempts to appeal to a wide audience - ex-residents and their children, interested locals, inter-state tourist and schoolchildren, each with their own expectations and ascribing and receiving their own collective memories of Bonegilla.

Public history sites can offer a space in which to communicate the multiple viewpoints involved in a contentious historical experience or episode. While the Heritage Park interacts with a number of mediums ext panels, videos, audio, physical remnants, life-sized visuals - perhaps the lack of oral testimony relating to Bonegilla has thwarted attempts to communicate a multiple and complex history. Hamilton and Shopes have written about the powerful use and function of oral history in the public arena, including its role in shaping collective memories. ${ }^{72}$ Staff at the Albury Library-Museum, much like site co-ordinator Zanet, bemoan the lack of oral testimony from former Bonegilla residents, especially in relation to the large and growing collection of physical remnants that exist in the Bonegilla Collection. They feel a significant part of the Bonegilla story is being lost. ${ }^{73}$ Steps are being made in this direction, especially by the online Belongings project conducted by the NSW Migrant Heritage Centre, and the written memory pieces sent into Albury Library-Museum's Bonegilla Collection by former residents. 
Overall, the Heritage Park neglects to sufficiently underline the different experiences of Bonegilla and the reasons behind these differences. The site is a de-contextualised and depoliticised representation of a select migrant journey. On one level, perhaps this deficiency is a reflection of the pained and contested layers of management Bonegilla has experienced since the late 1980s. The day-today management of the site has shifted from ex-resident volunteers, migrant volunteers from outside the Bonegilla community, to state and local heritage bodies with an eye to effective marketing without much significant context.

This is not to say that individuals and ethnic groups have not adopted their own use and interpretation of the site. The physical surrounds of the Hume Weir and the sounds of regional Victoria are familiar. And these sights and sounds can still evoke poignant memories for some migrant pilgrims. But the focus here is on publicly articulated versions of a collective past. Often, Greek and Dutch communities dominate the public history of Bonegilla. When I visited, the decade-old Dutch exhibition, 'Where Waters Meet', was contained in the room of one hut, while those nearby remained empty, still smelling of paint, and awaiting the installation of the newest exhibition by the Former Greek Residents Association. ${ }^{74}$ This exhibition, From Petronis and Ekaterina to Peter and Catherine: Greek Journeys Through Bonegilla, was launched in December 2011 by the Victorian Minister for Multicultural Affairs and Citizenship, Nicholas Kotsiras, whose Department had provided a \$13 000 grant to fund the project. Continuing official policy rhetoric, he promoted the exhibition as another commentary on the 'impact of postwar migrants in shaping a successful multicultural society'. But his position rests at the crossroads between vernacular and official, for he has his 'own roots to Bonegilla'. ${ }^{75}$

The Former Greek Residents Association has been particularly vocal in Bonegilla's recent commemorative history. Representations of the Greek experience of Bonegilla, while containing its own tragic moments, is typically dominated by the often exciting adventures of single men, there being the largest group among the Greek Bonegilla migrants. ${ }^{76}$ The leaders of the Residents Association object to any suggestion that Bonegilla was an awful place, a Spartan army camp in which the worst injustices of the immigration scheme were played out. Their fond views of Bonegilla have directed many popular representations, including those in Pennay's newly released booklet on the Greek experience at Bonegilla, funded by a Heritage Week Grant from the Commonwealth government. Their narratives often work in collaboration with official 
and popular ones: Bonegilla as the beginnings of multicultural Australia; or an epic landscape in which the early stages of the migrant success story are enacted. ${ }^{77}$

Site co-ordinator Zanet has admitted the experiences of these 1950s migrants have dominated the representation of Bonegilla on display at the Heritage Park These migrants arrived as separate national groups and were accommodated as such. Earlier displaced persons arrived as a mixed mass exodus, perceived by a naïve Australian public as a homogenous whole -'the Balts'. The earliest demographic studies have indicated that these Northern Europeans are more geographically dispersed, better 'integrated' - to adopt earlier sociological definitions and do not necessarily identify as members of a strong ethnic community. ${ }^{78}$ Pennay has also acknowledged that public memories displayed on site at the Heritage Park are determined by funding imperatives. To a larger extent, while the current Heritage Park is run by local government bodies, it also relies on enthusiastic ethnic communities to initiate their own exhibitions and celebrations. The Greek and Dutch communities have been most forthcoming in their support and encouragement for the commemoration of Bonegilla. Accordingly, they are successful in obtaining funding from state and commonwealth heritage agencies and the Victorian Multicultural Commission.

At the Heritage Park, the memories of earlier displaced persons are given token reference in the stories of the inadequacies of early camp conditions, the unlined huts, the lack of sanitary cleaning facilities and the standard of the food. These 'facts' contribute to the drama of the migrant success story. Indeed, these 'quick facts' feature on the help sheets given to new volunteers. While frequently cited, in the exhibitions the wider structural implications of these realities and their long-term impacts on the memories of early displaced persons are over-shadowed or sidelined by the experiences of migrants in the 1950s and 1960s. These particular migrants were separated in dormitories by nationality, rather than gender. They also gained superior facilities and confronted a less militarised system than that faced by early displaced persons.

Accordingly, the recollections of later assisted migrants differ somewhat from those of earlier displaced persons. The new exhibitions launched in September and the interpretation offered by the Heritage Park of Bonegilla's past has an emphasis on assisted migrants whose experiences are presented in a political and historical vacuum.

Bonegilla's newest government grant, and the promotion that surrounds it, further supports the processes of retrospective commemoration which seeks to construct Bonegilla as part of a national 
memory. Wodonga Council recently received over $\$ 60000$ to develop a 'business strategy' that will 'further extend the visitor experience as a viable tourist attraction and educational experience' ${ }^{79}$ Simone Hogg, the Council's manager of cultural services has stated: 'The Australian

Government grant will allow us to develop a clear business strategy that will examine potential revenues, improvements to the site entrance and links to other tourist attractions within the region to give the site longterm security. The business strategy will also explore the longevity of the site beyond the pilgrims (ex-residents and their families) and how to best communicate the Bonegilla migrant stories' ${ }^{80}$ Just how Bonegilla, as a site representing a unique period in Australia immigration history, will be linked to 'other tourist attractions within the region', is unclear. What is clear is that Bonegilla's meaning and significance is being consciously extended beyond the ex-residents involved in its earliest participatory memorialisation.

Inevitably, those who wish to remember their Bonegilla experiences, those people most comfortable with placing their personal histories alongside or within a nationalist framework, or even one that simply binds them with other ex-residents, are those most involved in its commemoration. Since the late 1990s, these people and groups have collaborated with state and local bodies with their own agendas and claims over the site and its significance. Bonegilla, rather than a site of contested memory, features as a homogenous representation of the migrant experience and the long-term successes of the post-war immigration scheme. Ex-residents are implicated in this success. Even migrant representatives and more localised bodies collaborate in these nationalist narratives that homogenise the migrant experience. Sluga also points out that some migrants prefer to concentrate on this potently present narrative of harmonious multiculturalism as a means to heal and give new meaning to past injustices.

The narratives on display at the revamped Heritage Park are public versions of a collective and state-sanctioned past. They sometimes rely on easy-to-assimilate tropes and resonant themes. Again, I refer to the migrant success story. We should be aware that not all stories can be easily communicated to local and national publics who hold certain expectations of National Heritage Sites. Experiences too complicated to communicate - desperation and isolation, depression and suicide, the strictures of the contract system and the subsequent family separation, the ongoing and provisional process of constructing belonging and a new sense of place - are necessarily pushed aside. Heritage sites or exhibitions on migration and multiculturalism focus on fixed and 
instrumental representations of experiences and people, 'stock narratives' to borrow a term from McShane. ${ }^{81}$ Nonetheless, I have tried to demonstrate that an interactive dialogue was and is inevitably at play in the construction of Bonegilla's public history, even as it has been part of a process of 'retrospective commemoration', framed by the limits of heritage and national discourses. As Ashton and Hamilton have observed: although the state endorses certain narratives within which communities must operate, 'memorial landscapes will reflect, in truly democratic societies, the values, experiences and dominant concerns of its citizens' ${ }^{82}$ Finally, I wish to assert that we cannot hope to understand Bonegilla's collective memory without tracing the history of the role of certain memory groups and actors and their negotiation within the discursive frameworks of Australian multiculturalism and national heritage that have developed since the 1980s.

\section{Endnotes}

${ }^{1}$ David Brown, Contemporary Nationalism: civic, ethnocultural and multicultural politics, Routledge, London, 2000, p2.

${ }^{2}$ Paul Ashton and Paula Hamilton, 'Places of the Heart: Memorials, Public History and the State in Australia since 1960', Public History Review, vol 15, 2008, p4.

${ }^{3}$ See, for example, Anna Haebich, Spinning the Dream: Assimilation in Australia 1950-1970,

Fremantle Press, North Freemantle, 2008.

${ }^{4}$ Catherine Panich, Santuary?: Remembering Postwar Immigration, Allen and Unwin, Sydney, 1988, p187.

${ }^{5}$ Glenda Sluga, Bonegilla: 'A place of no hope', The History Department, The University of Melbourne, Melbourne, 1988 px. David Cassidy and ПO, 'A History of Bonegilla', $A B C$ Doubletake, 10 August 1982.

${ }^{6}$ Howard Jones, 'Historic Camp Huts up for Sale Army Disposal Policy Shocks Museum Group', Border Morning Mail, 22 November 1986.

${ }^{7}$ Sara Wills, 'Between the Hostel and the Detention Centre: Possible Trajectories of Migrant Pain and Shame in Australia', in William Logan and Keir Reeves (eds), Places of Pain and Shame: Dealing with 'Difficult Heritage', Routledge, London, 2009, p269.

${ }^{8}$ See also, Paul Ashton, 'The Birthplace of Australian Multiculturalism? Retrospective Commemoration, Participatory Memorialisation and Official Heritage', in International Journal of Heritage Studies, vol 15, no 5, 2009, pp381-98.

${ }^{9}$ op cit, p25.

${ }^{10}$ Wulf Kansteiner, 'Finding Meaning in Memory: A Methodological Critique of Collective Memory Studies', History and Theory, vol 41, no 2, 2002, p190.

${ }^{11}$ See Glenda Sluga, 'Displaced: Loss of Identity in Immigrants to Australia and Expressions of This in Australian Literature', Meanjin, vol 48, no 1, 1989, pp153-60; Glenda Sluga, 'Bonegilla and Migrant Dreaming', in Kate Darian-Smith and Paula Hamilton (eds), Memory and History in Twentieth-Century Australia, Oxford University Press, Melbourne, 1994, pp195-209; Bruce Penny, 'Remembering Bonegilla: The Construction of a Public Memory Place at Block 19', Public History Review, vol 16, 2009, pp43-63; Bruce Pennay, “"But No One Can Say He Was Hungry”:

Memories and Representations of Bonegilla Reception and Training Centre', History Australia, vol 9, no 1, 2012, pp43-63; Jayne Persian, 'Bonegilla: A Failed Narrative', History Australia, vol 9, no1, 2012, pp64-83.

${ }^{12}$ Pennay, 'Remembering Bonegilla', pp43-63.

${ }^{13}$ ibid, p48.

${ }^{14} \mathrm{ibid}, \mathrm{p} 47$

${ }^{15}$ Persian, 'Bonegilla: A Failed Narrative', p67.

${ }^{16}$ The author volunteers at Melbourne's Immigration Museum.

${ }^{17}$ Albury Regional Museum, 'Bonegilla Stories and Memories: notebook', vol 1 and vol 2, from

The Bonegilla Collection', 1997-2001.

${ }^{18}$ Personal correspondence, 23 May 2011. 
${ }^{19}$ Sluga, Bonegilla, ppxi-xii.

${ }^{20}$ Sluga, 'Bonegilla and Migrant Dreaming'.

${ }^{21}$ Paula Hamilton, 'The Knife Edge: Debates about Memory and History', in Paula Hamilton and Kate Darian-Smith (eds), Memory and History in Twentieth Century Australia, Oxford University Press, Melbourne, 1994, p25.

${ }^{22}$ See also, Astrid Erll, 'Cultural Memory Studies: An Introduction', in Ansgar Nunning and Astrid Erll (eds), A Companion to Cultural Memory Studies, De Gruter, Berlin, 2010, pp1-18.

${ }^{23}$ Ashton, 'The Birthplace of Australian Multiculturalism?', p382.

${ }^{24}$ Iwona Irwin-Zarecka, Frames of Remembrance: The Dynamics of Collective Memory, Transaction Publishers, New Jersey, 1994, p4.

${ }^{25}$ For Greta, see Christopher Keating, Greta: A History of the Army Camp at Greta, New South Wales, 1939-1960, Uri Windt, Sydney, 1997.

${ }^{26}$ Desmond Cahill and John Ewen, Australian Youth Towards the Year 2001: a multicultural perspective, School of Community Services and Policy Studies, Phillip Institute of Technology, Melbourne, 1988, p10; we might also, in this instance, refer to World Expo 88'.

${ }^{27}$ Stephen Castles et al, 'The Bicentenary and the Failure of Australian Nationalism', in Race and Class, vol 29, no 3, 1988, pp53-68.

${ }^{28}$ Bruce Pennay, The Army at Bonegilla 1940-71, Parklands Albury-Wodonga, Wodonga, 2007, p19 and Howard Jones, 'Historic Camp Huts up for Sale Army Disposal Policy Shocks Museum Group', Border Morning Mail, 22 November 1986.

${ }^{29}$ Tony Wright, 'Border Migrants Push for National Museum at Army Site', Border Morning Mail, 12 July 1985

${ }^{30}$ Louis Maroya, 'Bonegilla Immigration Museum: A Meeting of Cultures: A Necessity in a Multicultural Australia. Workshop Paper', in FECCA Congress Report: Multiculturalism: a Commitment for Australia, Federation of Ethnic Communities' Councils of Australia, Canberra, 1988/9, pp227-37.

31 ‘Hurford Visits Migrant Camp', Border Morning Mail, 22 November 1986.

${ }^{32}$ R. Ashbourne, 'Migrant Relive the Bad Old Days', Sunday Mail SA, 10 February 1980, p26.

33 'Immigration Museum Kicks Off', Border Morning Mail, 17 July 1985 and Howard Jones, 'Museum is Closer', Border Morning Mail, 22 November 1985.

${ }^{34}$ Gretchen Miller, 'Gateway to new life for the dispossessed', Sydney Morning Herald, 6 February 1997; see also Albury City's Bonegilla Story website, http:/ / www.bonegilla.com.au/collection/ and Bonegilla Migrant Experience's website, http://www.bonegilla.org.au/.

${ }^{35}$ R. Ashbourne, 'Migrant Relive 'the Bad Old Days', Sunday Mail SA, 10 February 1980 and Sluga, Bonegilla, $\mathrm{px}$.

${ }^{36}$ Howard Jones, 'Historic Camp Huts up for Sale: Army Disposal Policy Shocks Museum Gorup', Border Morning Mail, 22 November 1986.

${ }^{37}$ Castles et al, 'The Bicentenary and the Failure of Australian Nationalism', p55.

${ }^{38}$ This, of course, eventually became Adelaide's Migration and Settlement Museum.

${ }^{39}$ For a contemporary discussion of the Bicentennial and the ABA see Peter Spearritt, 'Celebration of a Nation: the Triumph of Spectacle', in Australian Historical Studies, vol 23, issue 91, 1988, pp3-20.

${ }^{40}$ Ann Tundern-Smith, Bonegilla's Beginnings, Triple D Books, Wagga Wagga, 2007, p2.

The event was initially suggested by the Museum Committee in 1985.

${ }^{41}$ Sluga, Bonegilla, pp131-39.

${ }^{42}$ Terry McGovern, 'Return to the Unforgettable', Sun Herald, 11 October 1987 and Pamela Bone, 'The Chosen People', The Age, 28 November 1987.

${ }^{43}$ Sluga, Bonegilla, p207.

${ }^{44}$ Ruth Daniel and Freeman Leeson Architects, Block 19 Bonegilla Conservation Management Plan vol 1: Conservation Analysis, prepared for Department of Defence, October 1996, p36.

${ }^{45}$ Bruce Pennay, 'Significance Assessment: The Bonegilla Collection at Albury Library Museum', Charles Sturt University, Albury, 2008, p8.

${ }^{46}$ Vikki Kyriakopoulos, 'Migration Memorial', Bulletin, 30 September 1997, pp30; 32.

${ }^{47}$ Ruth Daniel and Freeman Leeson Architects, Conservation Management Plan.

${ }^{48}$ Jane Braslin, 'Insight: Bonegilla', Insight, SBS, 1997 and Leigh Dale, 'Mainstreaming Australia', Journal of Australian Studies, vol 21, no 53, 1997, pp9-19.

${ }^{49}$ Kyriakopoulos, 'Migration Memorial'.

${ }^{50}$ Howard Jones, 'Minister Cold on Plea to Preserve Migrant Camp', Border Mail, 11 May 1996.

${ }^{51}$ See, for example, Jane Braslin (journalist), 'Insight: Bonegilla', Insight, SBS, 1997.

${ }^{52}$ Geraldine O'Brien, 'Looked Down on Then, Migrants Build a Nation', Sydney Morning Herald, 3 July 1997 and L. Gans, 'A Suitcase Full of Memories', Courier Mail, 18 April 1997 and Gretchen Miller, 'Gateway to New Life for the Dispossessed', Sydney Morning Herald, 6 February 1997.

${ }^{53}$ Dirk and Marijke Eysbertse, Where Waters Meet: Bonegilla: The Dutch Migrant Experience, The Erasmus Foundation, Melbourne, 1997. 
${ }^{54}$ Penny, 'The Army at Bonegilla', p19.

${ }^{55}$ As Pennay himself has demonstrated in 'Remembering Bonegilla'.

${ }^{56}$ Many residents of Albury and Wodonga still remember Bonegilla first as an army camp.

${ }^{57}$ City Council Wodogna and City Council Albury, '1999 Bonegilla Festival Guide', Albury Wodonga, 1-4 October 1999.

${ }^{58}$ Jayne Persian, 'Displaced Persons (1947-192) Representations, Memory and Commemoration', PhD thesis, Department of History, The University of Sydney, 2011.

${ }^{59}$ Penny, personal correspondence.

${ }^{60}$ Mary Hutchison, 'Dimensions for a Folding Exhibition: Exhibiting Diversity in Theory and Practice in the Migration Memories Exhibitions', in Humanities Research, vol 15, no 2, 2009, pp7173.

${ }^{61}$ Lee Mylne, 'Return to Bonegilla', The Australian, August 252007.

${ }^{62}$ ibid.

${ }^{63}$ Bruce Pennay, 'Framing Block 19 Bonegilla for Tourist and Local Visitors', Historic Environment, vol 21, no 3, 2008, pp27-33.

${ }^{64}$ Brad Worrall, 'Block 19 Seen as Core of Tourism Push', The Border Mail, 5 January 2010; Brad Worral, 'Time to Make Block 19 a Tourist Magnet', The Border Mail, 27 August 2011; Sue Wallace, 'A Tribute to New Arrivals', The Age, Traveller, Saturday, 9 July 2011; 'Bonegilla a great story', The Border Mail, 27 August 2011.

${ }^{65}$ Bernadette Zanet, personal correspondence, 24 May 2011.

${ }^{66}$ As according to the new Victorian high school curriculum, which includes Bonegilla.

${ }^{67}$ Wills, 'Between the Hostel and the Detention Centre', pp272-277.

${ }^{68}$ ibid, p266.

${ }^{69}$ ibid.

${ }^{70}$ Bernadette Zanet, personal correspondence, 24 May 2011.

${ }^{71}$ For an extended discussion see Mary Hutchison, 'Dimensions for a Folding Exhibition', pp71-73 and Ian McShane, 'Challenging or Conventional? Migration History in Australian Museums', in Negotiating Histories : National Museums Conference Proceedings, in Darryl McIntyre and Kirsten Wehner (eds), National Museum of Australia, Canberra, 2001, pp122-33.

${ }^{72}$ Paula Hamilton and Linda Shopes (eds), Oral History and Public Memories, Temple University Press, Philadelphia, 2008.

${ }^{73}$ Personal correspondence, 23 May 2011.

${ }^{74}$ This exhibition was launched in December 2011.

75 'New exhibition celebrates Greek odyssey', November 2011, available:

http:/ / www.bonegilla.org.au/block19/whatson/bonegillaexh.htm.

${ }^{76}$ Bruce Pennay, Greek Journeys through Bonegilla, Parklands Albury-Wodonga, Wodonga, 2011, pp4-5.

${ }_{77}$ 'New exhibition celebrates Greek odyssey', November 2011, available: http:/ / www.bonegilla.org.au/block19/ whatson/bonegillaexh.htm.

${ }^{78}$ See, for example, Jerzy Zubrzycki, Immigrants in Australia: A Demographic Survey Based Upon the 1954 Census, Melbourne University Press on behalf of the Australian National University, Melbourne, 1960.

${ }^{79}$ The Bonegilla Migrant Experience, 'Bonegilla backing to build on visitor boost', available: http://www.bonegilla.org.au/block19/whatson/bonegillagrant.htm.

${ }^{80}$ ibid.

${ }^{81}$ Ian McShane, 'Challenging or conventional? Migration history in Australian museums', in McIntyre and Wehner (eds), Negotiating Histories, pp122-133.

${ }^{82}$ Ashton and Hamilton, 'Places of the Heart', p26. 